DOI: $10.2478 / \mathrm{v} 10014-008-0017-2$

Agrovoc descriptors: agaricus; edible fungi; fruiting; crop yield; crop performance; carbon dioxide; composts; top soil; growing media

Agris category code: F01; P35

COBISS code 1.01

\title{
Influence of carbon dioxide, inoculum rate, amount and mixing of casing soil on Agaricus blazei fruiting bodies yield
}

\author{
Andrej GREGORI ${ }^{1}$, Bojan PAHOR $^{2}$, Roman GLASER ${ }^{3}$, Franc POHLEVEN ${ }^{4}$
}

Received March 05, 2008; accepted August 22, 2008

Delo je prispelo 5. marca 2008, sprejeto 22. avgusta 2008

\section{ABSTRACT}

Influence of carbon dioxide concentration during compost and casing soil overgrowth, inoculum rate, casing soil depth and mixing on Agaricus blazei fruiting bodies yield was determined. Compost composed of chicken manure and wheat straw which is used for commercial button mushrooms cultivation in Slovenia showed to be appropriate for $A$. blazei fruiting bodies production. Out of the parameters tested in our experiments, casing soil depth and inoculum rate had the biggest positive effect on fruiting bodies production. For $A$. blazei fruiting bodies production higher rates of inoculum and at least $8.5 \mathrm{~kg}$ of commercial casing soil per square meter of compost surface should be used. Higher carbon dioxide concentrations shoved to be beneficial for attaining higher yields of $A$. blazei fruiting bodies.

Key words: Agaricus blazei, casing soil, mushroom cultivation, compost

1 B.A. agronomy, SRC Bistra Ptuj, Slovenski trg 6, 2250 Ptuj, Slovenia

2 dr.., Perutnina Ptuj d.d., Potrčeva cesta 10, 2250 Ptuj, Slovenia

3 dr.., Perutnina Ptuj d.d., Potrčeva cesta 10, 2250 Ptuj, Slovenia

4 Prof. dr., Department of Wood Science and Technology, Biotechnical Faculty, University of Ljubljana, Rožna dolina, Cesta VIII/34, 1000 Ljubljana, Slovenia

All experiments were performed at the mycology laboratory of Institute of Natural Sciences, Podkoren 72, 4280 Kranjska gora.

Address all corespondence to Andrej Gregori, SRC Bistra Ptuj, Slovenski trg 6, 2250 Ptuj, Slovenia, E-mail: andrej.gregori@gmail.com 


\section{IZVLEČEK}

\section{VPLIV OGLJIKOVEGA DIOKSIDA, KOLIČINE GLIVNEGA VCEPKA IN KOLIČINE TER MEŠANJA KROVNE PRSTI NA PRIDELEK GOB VRSTE Agaricus blazei}

Raziskovan je bil vpliv koncentracije ogljikovega dioksida med preraščanjem komposta in krovne prsti (pokrivke), količine glivnega vcepka primešanega kompostu ter količine krovne prsti in mešanje le-te po preraščanju s podgobjem na obrod gob Agaricus blazei. Kompost pripravljen iz kurjega gnoja ter pšenične slame, ki ga izdelujejo ter na območju Slovenije uporabljajo za komercialno gojenje šampinjonov, se je izkazal kot primeren za gojenje gob vrste A. blazei. Med testiranimi parametri gojenja sta na povečanje pridelka vplivali predvsem količina krovne prsti in koncentracija glivnega vcepka vmešanega $\vee$ kompost. Za uspešno gojenje je potrebno uporabiti vsaj $8,5 \mathrm{~kg}$ komercialne krovne prsti na kvadratni meter komposta. Višje koncentracije ogljikovega dioksida in pokrivke pozitivno vplivajo na obrod gob.

Ključne besede: Agaricus blazei, pokrivka, gojenje gob, kompost

\section{INTRODUCTION}

The biggest Slovenian poultry producer Perutnina Ptuj d.d. is facing a problem caused by large quantities of poultry manure. One of potential solutions for solving this problem is its use as a mushroom compost component. Cultivated mushrooms could be used as an additive in human food products produced by Perutnina Ptuj d.d., raising the quality of this products if medicinal mushrooms like $A$. blazei were to be used. Cultivation of this mushroom could represent an excellent solution for conversion of poultry manure into more stable form, solving problems with disposal and also creating a place for additional activities - working places, new product fabrication, raising quality of old products, additional income etc.

Brazilian blazei mushroom has been referred to by various names, most commonly as Agaricus blazei Murrill (sensu Heinemann) and recently as Agaricus brasiliensis (Kerrigan, 2005). The mushroom is best known in Japan as Himematsutake or Kawariharatake, in China as Gee Song Rong or Brazilian mushroom, and in Brazil as mushroom of God (Cogumelo de Deus) or mushroom of the Sun (Cogumelo do Sol). Cultivation centers of A. blazei are now well-established in Brazil, Japan, China and Korea. There are also growers in Thailand and throughout the Far East, Denmark and the Netherlands, as well as the United States. Today, Japan is the number one in consumption, and is the most sought-after market for A. blazei, one of the most expensive gourmet medicinal mushrooms in Japan (Chen, 2003). Its ingredients and numerous medicinal effects have been reviewed by Mizuno (2002). A. blazei cultivation was described by Chen et al. (1999), Royse (2001), Park (2001), Choi (2002) and Mendonca et al. (2004).

According to Kwon (2001), cultivation of Agaricus blazei mushroom differs from others in the following:

- A. blazei cultivation is quite similar to white button mushroom (A. bisporus) cultivation, but it favors higher temperature and lighting (even during spawn run),

- A. blazei is a secondary saprophyte, which grows on material already partially degraded by microorganisms, requiring fermented compost as substrate, unlike 
other primary saprophytes such as Shiitake (Lentinula edodes), Maitake (Grifola frondosa) and Reishi (Ganoderma lucidium),

- A. blazei is less prone to mold-infestation than other mushroom species.

In natural habitats, these mushrooms are found on organic litter which has already been occupied by the first stage decomposers capable of digesting complex lignocellulosic components. Being a second-stage decomposer, A. blazei can only be cultivated on fermented substrates after the complex basal components are partially broken down into simpler ones (Chen, 2003). Much of the cultivation technology for A. blazei has been adapted from growing A. bisporus, the white button mushroom. The major differences between growing the two species are the higher temperature needed for A. blazei and the light needed for fruiting bodies development (Stamets, 2000).

The aim of our experiment was to determine which cultivating parameters influence A. blazei fruiting bodies yield the most. Carbon dioxide concentration during compost and casing soil overgrowth, casing soil depth, mixing of overgrown casing soil and concentration of spawn mixed into the compost were tested.

\section{MATERIALS AND METHODS}

\subsection{Fungal culture}

Fungal culture strain 7700 used in our experiment was purchased at Mycelia Company (Nevele, Belgium) and maintained on Potato Dextrose Agar (PDA) at $24^{\circ} \mathrm{C}$.

\subsection{Compost preparation}

Compost was prepared in commercial compost producing facility of the Fungus d.o.o. Company (Ribnica na Pohorju, Slovenia). The preparation technique was the same as for white button mushroom compost production. Compost was prepared by mixing 80 parts of chicken manure, 100 parts of wheat straw and 3 parts of gypsum. After wetting the mixture was composted outside for seven days, pasteurized for six days and conditioned for six days in a pasteurization chamber.

\subsection{Fungal inoculum preparation}

Wheat grains were soaked in excess water overnight and then boiled until $50 \%$ moisture content was achieved. Cooked grains were mixed with $\mathrm{CaCO}_{3}(0.6 \%$ dry weight) and gypsum ( $1.8 \%$ dry weight) and filled into 2.4 liter glass jars. Jars were covered with metal lids having 14 $\mathrm{mm}$ diameter hole filled with cotton for gas exchange and sterilized for three hours at $121^{\circ} \mathrm{C}$. When PDA surface was overgrown with fungal culture it was used for inoculation of sterilized grains.

Inoculated grains were briskly shaken to achieve even distribution of fungal culture and incubated one month in a dark place at $24 \pm 1^{\circ} \mathrm{C}$. When grains were completely overgrown by mycelia they were used as a spawn for compost inoculation.

\subsection{Experiment design}

$3 \mathrm{~kg}$ of compost was filled into round $25 \mathrm{~cm}$ high and 30 wide black plastic containers with holes in the bottom. Tests were performed in triplicates. Compost had $61 \%$ moisture content (determined with drying for 24 hours at $103{ }^{\circ} \mathrm{C}$ ). Different proportions $(1,2$, and $5 \%$ ) of spawn were mixed into compost (Table 1.). Where higher $\mathrm{CO}_{2}$ during mycelia overgrowth was tested, Styrofoam boards (1 $\mathrm{cm}$ thickness) were laid on top of containers, disabling active gas exchange between interior of the container and surrounding environment. 
Table 1. Experimental design

\begin{tabular}{|c|c|c|}
\hline & & spawn rate (\%) \\
\hline \multirow{9}{*}{$2.4 \mathrm{~kg}$ casing soil } & \multirow{3}{*}{ no mixing } & 1 \\
\hline & & 2 \\
\hline & & 5 \\
\hline & \multirow{3}{*}{ mixing } & 1 \\
\hline & & 2 \\
\hline & & 5 \\
\hline & \multirow{3}{*}{ stirofoam } & 1 \\
\hline & & 2 \\
\hline & & 5 \\
\hline \multirow{9}{*}{$1.4 \mathrm{~kg}$ casing soil } & \multirow{3}{*}{ no mixing } & 1 \\
\hline & & 2 \\
\hline & & 5 \\
\hline & \multirow{3}{*}{ mixing } & 1 \\
\hline & & 2 \\
\hline & & 5 \\
\hline & \multirow{3}{*}{ stirofoam } & 1 \\
\hline & & 2 \\
\hline & & 5 \\
\hline
\end{tabular}

Containers filled with inoculated compost were placed in a dark place with constant temperature of $22 \pm 1{ }^{\circ} \mathrm{C}$ and $80 \%$ relative humidity. Aeration was set to minimum $\left(1600 \mathrm{ppm} \mathrm{CO}_{2}\right)$. When compost was completely overgrown with mycelia the casing soil with $76.8 \%$ water content was applied. 2.4 and $1.4 \mathrm{~kg}$ of casing soil was applied.

When mycelia completely overgrown the casing soil it was mixed in one third of the containers. Afterwards containers filled with casing soil were exposed to the temperature of $17 \pm 1{ }^{\circ} \mathrm{C}$ for fruiting bodies induction. After cold shock treatment containers were moved back into the growth room with air exchange set to maximum, 10 hours of daily light period and $90 \%$ relative humidity.

Fruiting bodies were harvested when caps were closed, with partial veil unbroken. Their weight was determined.

All the experiments were conducted at the mycological laboratory of Institute of Natural Sciences (Podkoren, Slovenia).

\section{RESULTS AND DISCUSSION}

In compost inoculated with $1 \%$ of $A$. blazei spawn during the whole cultivating procedure fruiting bodies yields were the highest when $2.4 \mathrm{~kg}$ of casing soil and covering of containers with Styrofoam or mixing was used. Yield was the lowest when $1.4 \mathrm{~kg}$ of casing soil was used and containers were covered with Styrofoam (Picture 1.). 


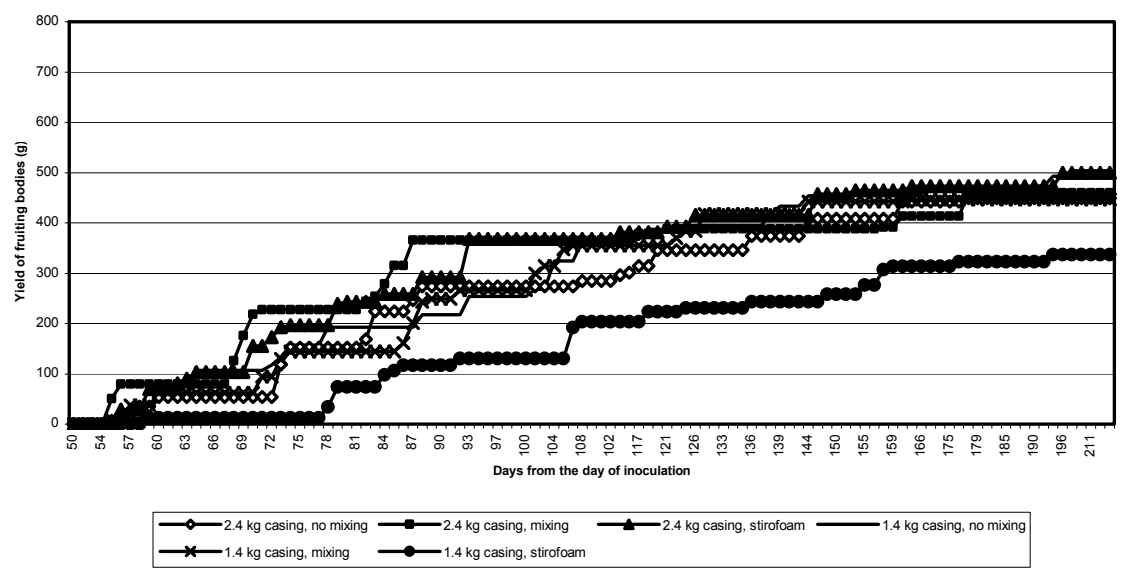

Figure 1: Fruiting bodies yield on compost inoculated with $1 \%$ spawn rate during the whole cultivation period

When $2 \%$ spawn rate was used at the beginning of the cultivation procedure yields were higher in containers with $2.4 \mathrm{~kg}$ of casing soil without mixing. At the end of cultivation (after day 211) the yield was higher in containers with $2.4 \mathrm{~kg}$ of casing soil covered with Styrofoam during faze of overgrowth. Yields were the lowest when $1.4 \mathrm{~kg}$ of casing soil was used and containers were covered with Styrofoam (Picture 3.).

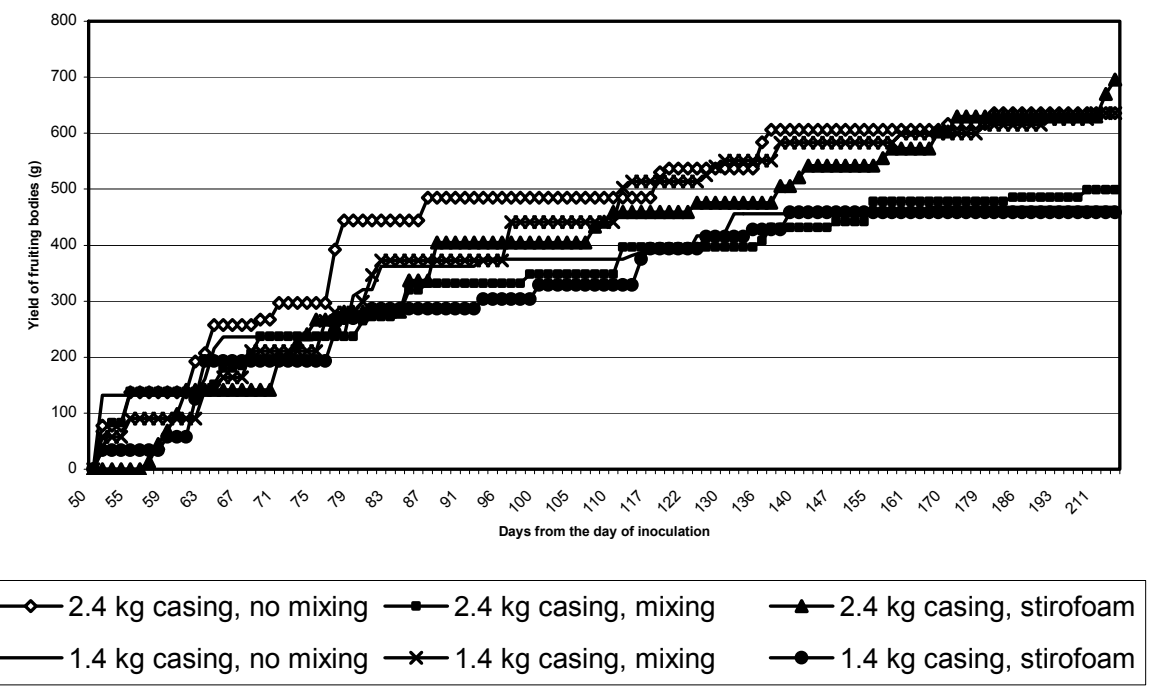

Figure 2: Fruiting bodies yield on compost inoculated with $2 \%$ spawn rate during the whole cultivation period 
When $5 \%$ spawn rate was used at the start of the cultivation procedure yields were higher in containers with $1.4 \mathrm{~kg}$ of casing soil with mixing. From the day 91 yield was the highest in containers with $2.4 \mathrm{~kg}$ of casing soil covered with Styrofoam during faze of overgrowth. Yields were the lowest when $1.4 \mathrm{~kg}$ of casing soil was used and containers were covered with Styrofoam boards (Picture 3.).

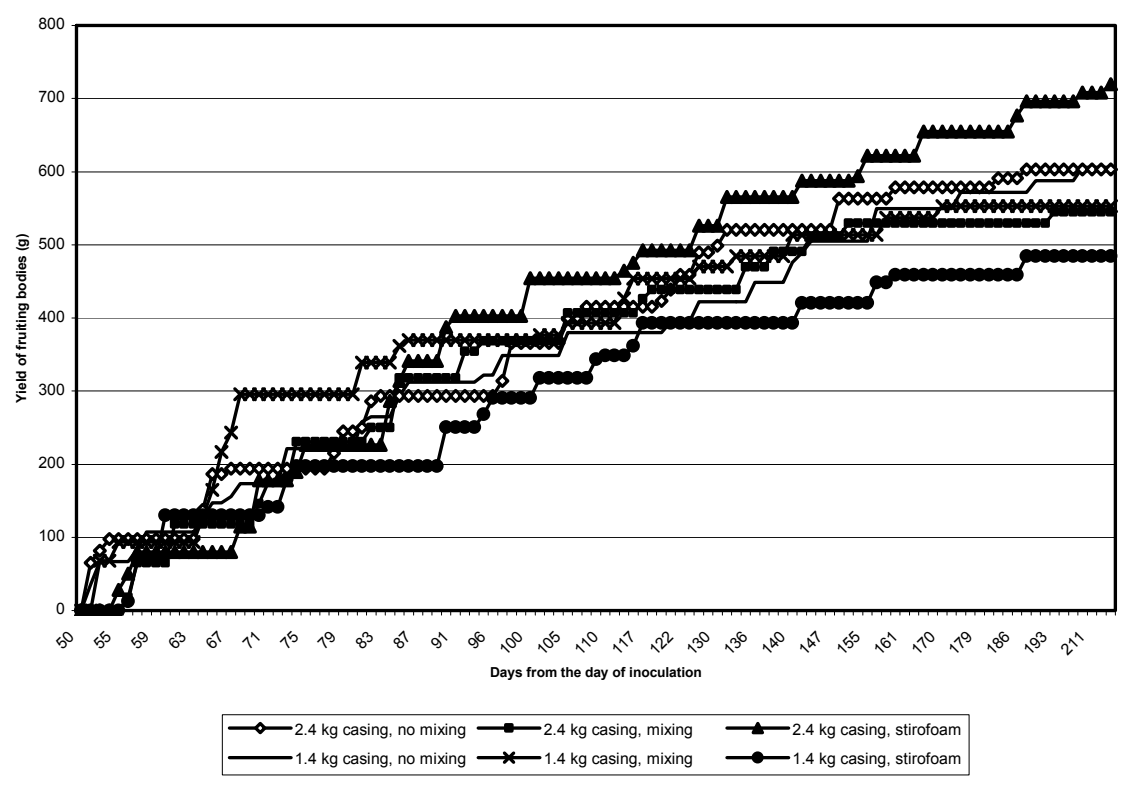

Figure 3: Fruiting bodies yield on compost inoculated with $5 \%$ spawn rate during the whole cultivation period

At higher $\mathrm{CO}_{2}$ concentrations during the incubation phase casing soil tends to plays an important role in fruiting bodies development. Yields were $49 \%$ higher in average when $2.4 \mathrm{~kg}$ instead of $1.4 \mathrm{~kg}$ of casing soil was used.

When $2.4 \mathrm{~kg}$ of casing soil was used mixing had a negative influence on yield when $2 \%$ (22 \% yield reduction) and $5 \%$ (10\% yield reduction) of spawn rate was used. When $1 \%$ spawn rate was used yield was increased for $2 \%$ in mixed casing soil.

At $1.4 \mathrm{~kg}$ of casing soil, mixing had a negative effect on fruiting bodies yield when $1 \%$ (11\% yield reduction) and $5 \%$ (9\% yield reduction) spawn rate was used (Picture 1., Picture 3.). When $2 \%$ spawn rate was used yield was greatly increased (36\%) in mixed casing soil (Picture 2., Picture 4.).

The major influence on $A$. blazei yield is caused by casing soil depth and spawn quantity used for compost inoculation. When higher rates of spawn are used for compost inoculation yields tend to be higher. Yields are $26 \%$ higher in average when instead of $1 \% 2 \%$ of inoculum were used and $3 \%$ in average if instead of $2 \%$ $5 \%$ inoculum rate was used (Picture 4.). 


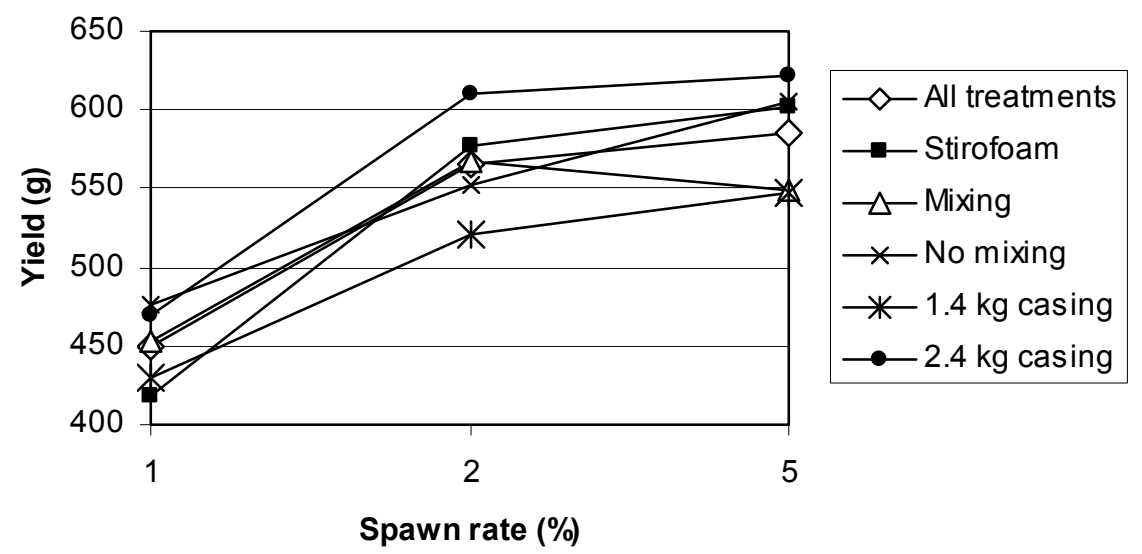

Figure 4: Average fruiting bodies yield at different treatments (Average yield at two different casing soil weights was calculated.)

\section{CONCLUSIONS}

Compost composed of poultry manure and wheat straw which is used for commercial A. bisporus cultivation, showed to be appropriate for A. blazei fruiting bodies production. Out of the parameters tested in our experiments, casing soil depth and inoculum rate had the principal positive effect on fruiting bodies production. We can conclude that for $A$. blazei fruiting bodies production higher rates of inoculum and at least $8.5 \mathrm{~kg}$ of casing soil per square meter of compost surface should be used. Higher carbon dioxide concentrations during mycelium overgrowth also shoved to be beneficial for attaining higher A. blazei fruiting bodies yields.

Also other fungal strains should be tested to determine weather the effects of parameters researched in our study are strain dependent. From economical point of view the optimal cultivation process length should be determined, although the process can last for a long time.

Although compost composed of chicken manure and wheat straw can be successfully used for $A$. blazei cultivation it can be implemented into other activities conducted by big poultry producers, solving their problems with manure disposal and representing other possibilities of fruiting bodies usage (additives to food and feed products).

\section{ACKNOWLEDGEMENTS}

This research was financed by Slovenian Research Agency (applicative research project No. L2-7598), Perutnina Ptuj d.d. and Municipality of Ptuj, we would like to 
thank all of them for their support. We would also like to thank to Aleš Jezeršek for his help with performing the experiments.

\section{REFERENCES}

Chen, A. W. 2002: A Practical Guide to the Cultivation of Agaricus blazei, a Mushroom of Culinary and Biomedical Importance. www.mushworld.com, visited in 2006.

Chen, A. W., Stamets, P., Huang, N.L. 1999: Compost-substrate fermentation and alternatives for successful production of Agaricus blazei, Proceedings of $3^{\text {rd }}$ International Conference of Mushroom Biology and Mushroom Products, October 1999, Sydney, Australia.

Choi, K. W. 2002: The Joy of Growing Agaricus blazei Murrill - a Case of Korea (1). www.mushworld.com, visited in 2006.

Kerrigan, R. W. 2005: Agaricus subrufescens, a cultivated edible and medicinal mushroom, and its synonyms._Mycologia, 97: 12-24.

Kwon, H. J. 2001: There's something about Agaricus blazei. www.mushworld.com, visited in 2006.

Mendonca, M., Kasuya, M. C., Cadorin, A., Vieira, A. J. 2004: Agaricus Blazei cultivation for living in Brasil. Mushroom growers handbook, Mush World: 208-218.

Mizuno 2002: Medicinal properties and clinical effects of culinary-medicinal mushroom Agaricus blazei Murill (Agaricomycetidae). International Journal of Medicinal Mushrooms, 4: 299-312.

Park, J. S. 2001: Characteristics and Cultivation technology of Agaricus blazei. www.mushworld.com, visited in 2006.

Pohleven F. 1990: Significance of mushroom cultivation for nutrition and for environmental protection. In: Utilization and protection of forest mycoflora, Workshop proceedings, Ljubljana 26. - 27. September 1990.

Royse, D. J. 2001: Six Steps to Mushroom Farming. www.mushworld.com, visited in 2006.

Stamets, P. 2000: The Himematsutake mushroom of the genus Agaricus, Agaricus blazei Murrill. In: Stamets, Paul, Growing Gourmet and Medicinal Mushrooms. Ten Speed Press, Berkeley, CA. 